SECTION 29. Literature. Folklore. Translation Studies.

Zhibek Amirovna Otesh

lecturer of the Department "Philology and journalism",

M.Kh. Dulaty Taraz State University, Kazakhstan

jiboj@mail.ru

\title{
ROLE BAUIRZHAN MOMYSHULY IN THE KAZAKH MILITARY PROSE
}

Abstract: The article focuses on the formation of the military literature in Kazakh prose. Since the theme of the Second World War was not considered as an art, professional writers not to bother giving a picture of the war years and the more distortion of history. But being a participant in the war, and as the founder of military subjects in Kazakh literature B.Momyshuly defined the role and importance of military literature.

Key words: Great Patriotic War, the military prose, artwork.

\section{РОЛЬ БАУЫРЖАНА МОМЫШҰЛЫ В КАЗАХСКОЙ ВОЕННОЙ ПРОЗЕ}

Аннотация: Статья посвящена вопросу становления военной литературы в казахской прозе. Так как тема ВОВ не рассматривалась как художественная, профессиональные писатели не брались описывать картину военных лет и тем более искажать историю. Но будучи участником войны и как основоположник военной тематики в казахской литературе Б.Момьшұль определил роль и значение военной литературы.

Ключевые слова: Великая Отечественная Война, военная проза, художественное произведение.

\section{КАЗАҚТЫН ӘСКЕРИ ПРОЗАСЫНДАҒЫ БАУЫРЖАН МОМЫШҰЛЫНЫН ОРНЫ}

Әлем әдебиетінде, соның ішінде қазақ прозасында әскери тақырып жайына, соғыс жайлы көптеген шығармалар жазылғанмен, шынайылылығы, көркемдік сипаты мен талғамдық дәрежесі бірдей болған жоқ. Соғыстың қатал ақиқаты мен болмысы, психологиясы терең ашылып жатпады. Бір жағынан оны жазушылардың сол қанды майданға тікелей қатынаспауында болса, екінші себебі кеңестік идеологияның ықпалынан еді. Осы орайда әдебиетші ғалым М.Қаратаев: «Жеке басқа табынушылықтың салдары көркемдік дамуға да тимей қойған жоқ. Теория мен тәжірибенің арасындағы алшақтық, советтік әділ заңды, демократияны бұзушылық, жеке басты жөнсіз дәріптеп, барлық жеңіс пен табысты бір адамның басына таңу, халықтың рөлін жете бағаламау секілді жайлар осы құбылыстың салдары болатын» [1, 84-б] - деп жазды.

Мұндай олқылық тек қазақ әдебиетінде емес, көрші халықтардың әдебиеттерінде де көрініс тапты. Әдебиеттанушы С.И. Журавлев соғыс тақырыбында іле-шала жазылған туындыларда оқиғаны әсірелеп беру, әлсіз психологизм, иллюстрациялылық, жағымды және жағымсыз геройларды тіке қарсы қою, соғысты белгілі мөлшерде романтикаландыру секілді кемшіліктер болғанын айтады [2, 14-б].

Осы орайда Бауыржан Момышұлы майдан шындығының дұрыс бейнеленуі мәселесін соғыс жылдарында-ақ айтқандардың бірі болды. Ел басшыларына да, әдебиет қайраткерлеріне жазған хаттарында соғыс шындығының шынайы жазылуын талап етті. Әскери әдебиеттің қалыптасып дамуына ат салысқан қайраткерлердің бірі болды. Майдан өмірін бейнелеуде табыстары да мол еді. Бұл жайт оған оңай берілмесе де, бар қажырқайратын әдебиет майданында, бойына біткен дарындылығымен жұмсай білді. Қазақ әдебиетіндегі поэзия, проза жанрларын әскери тақырыппен толықтырды. Әсіресе адам 
әлемін, ондағы әділеттілік пен адалдық секілді биік қасиет-өлшемдерді әр қырынан танытып, мән-маңызын арттыра түсті. Осы арқылы жас ұрпақты ерлік пен елдікке үндеді, ұлттық мақсат-мұраттарға, ар-намыс алдындағы шынайы көріністерін танытуға бағытбағдар береді. Өмірінің соңына дейін осы бағыт-сипатын да ұлы мұрат етті.

«Тағдыр мені адамзаттың жан түршігерлік қайғы-қасіретінің куәгері болуға жазса да, ақ қағаздың бетіне болат қаламсаптың ұшымен қисынды сөзді маржандай етіп тізе алатындай өнерім болса да жай себеппен, менің қолым жауға сілтер қылыштың сабын ұстауға, пистолеттің шүріппесі мен жауынгердің атының тізгінін ұстауға үйренген қолыма - қаламсап та, уставтың өктем бұйрығына үйреніп қалған тілім де ырық берер емес, бірақ та сараңдардың санатында (өлер алдында бар байлығын босқа далаға шашқан Қарымбай сияқты) қалмас үшін, өлгендердің рухы, зардап шеккен, адал солдаттарымның алдында үн-түнсіз қалмауға, бастан кешкендерді тілсіз қағаз бетіне түсіруді өзіме парыз санаймын, өйткені ол: «ерлік елеусіз қалмасын, олжа - елге, атақ - ерге сауға» деген әділеттілік қағидасын еске салатын, шындық оқиға куәгерінің тілі болсын» [3, 17-б].

Бауыржан Момышұлының өмір сүрген кеңес заманында барлық халықтар үшін, соның ішінде Қазақстан халқы үшін де ел басына күн туған шақта Ұлы Отан соғысының қазақ прозасындағы тақырыбы жайлы жауынгер-жазушы сол сұрапыл жылдарда талай мінберден сөйлеген еді. Қазақстанның әдебиеті мен өнері қазақ халқының соғыс жылдарында жасаған ерлігінің, тыл жұмысшыларының берген көмегінің көрінісі бола отырып, қазақстандықтарының рухани күшінің дамуына себеп болды. Б.Момышұлы майданда болған қазақ жазушылары жөнінде өзінің «Тема Великой Отечественной войны в казахской прозе» деген баяндамасында егжей-тегжейлі атап көрсетті. Жауынгер-жазушы бұл баяндамасында көптеген қазақ жазушыларының шығармаларына талдау жасайды. Оның ішінде Ғ.Мүсіреповтың «Қазақ солдаты», Т.Ахтановтың «Қаһарлы күндер», Ә.Нұрпейісовтың «Курляндия», «Желанный день», сондай-ақ панфиловшы жауынгерлерінің ерлігі жайлы сол қатарда болған М.Ғабдулиннің «Менің майдандас достарым», Д.Снегиннің «В наступлении» шығармаларына тоқталып өтті.

Бұл тақырыпта, яғни Қазақстанның Ұлы Отан соғысында алар орны жайлы әрбір жазушының негізге алатын, әрі сүйенері тек соғысқа қатысқан жауынгерлердің естеліктері бола бермек. Б.Момышұлының осы мәселені, сондай-ақ, бүкіл әлемді дүр сілкіндірген Ұлы Отан соғысы туралы тарихи шынайы деректерді тек тірі куәгерлерінің естеліктерінен ғана білу мүмкіндігін ескертеді. Онсыз да жыл сайын қатары сиреп бара жатқан ардагерлердің соғыс жайлы мағлұматтарын пайдалану қажеттігі артып тұрғанын естен шығармауды да айтқан болатын. Бұған дәлел ел басшыларына жазылған майдан хаттарынан білуге болады. Осы мәселені қолға алып, алдағы жылдары да кезек күттірмейтін мәселелердің бірі екенін атап өтті.

Ұлы Отан соғысының атақты қолбасшысы, гвардия полковнигі соғыс аяқталғаннан кейін де қолжазбаларын, күнделіктерін қайта қарап, тарихилығымен қатар, тәрбиелік мәні зор шығармаларын жазды. Оның ең алғаш жарық көрген шығармасы - «Бір түннің оқиғасы» болды. Мұнда өзінің жауынгер достары, Кеңес Одағының батырлары, ерлікпен қаза тапқан Төлеген Тоқтаров пен Мәлік Ғабдуллин және тағы басқа да шығармалары жақсы қабылданды. Қазақ көркем өнерінің Мәскеуде өткен онкүндігі қарсаңында өзінің ең үлкен, әрі көлемді шығармасы - «Москва үшін шайқас» романы орыс тілінде жарық көрді. Бұл еңбек оның майдандас жолдастары мен панфиловшы батырларына арналған мәңгілік рухани ескерткіші болды. Олардың ерлік істеріне, бүкіл дүниежүзін өзіне қаратқан, таң қалдырған батырлық пен тапқырлық қимылдарына арналған бірден-бір еңбек болды. Мұндағы жауынгер жігіттер Төлеген Тоқтаровтың, Мұқаметқұл Исламқұловтың, Грицко Проценконың, Алексей Алешиннің естен кетпес образдарымен қатар, әрі командир, әрі ұстаз, қолбасшы генерал И.В. Панфиловтың, генерал Чистяковтың, өзінің ең алғаш әскери ұстазы Рединнің, полковник Павел Вахалов тәрізді ер жүрек адамдардың бейнелері кездеседі. 
Жауынгер-жазушының шығармашылығына оқырман қауым соншалықты ықыласын білдіргендігінің мәні неде деген сұрақ туындайды. Біріншіден, Б.Момышұлы қазақ әскери прозаның негізін қалаған бірден-бір жазушы болды. Бұл оның соғыс тақырыбына арналып жазылған көптеген туындылары дәлел. Сол сұрапыл соғыс жылдарын басынан өткерген Б.Момышұлы өз шығармаларында суреттелетін әрбір детальға қырағылық танытып, соғыстан кейінгі еңсесін енді ғана көтеріп келе жатқан елге тарихи шындықты жеткізуді мақсат етті. Ақиқатты, шындықты басты мұрат еткен Б.Момышұлы өз көздеген мақсатына жетті де. Екіншіден, көптеген шығармаларының кейіпкерлері - зұлмат соғыста қаза тапқандар мен соғыстан елге оралғандар еді, яғни олар қанды шайқасты өз көздерімен көрген жауынгерлер. Осылайша шығармалардың авторы мен кейіпкерлері, яғни соғыс ардагерлері халық арасында жүруі де оқырман қауымның жауынгер-жазушының творчествосына деген қызығушылықтарын екі есе арттыра түсті. Ал, үшіншіден, қалың оқырман ішінен жастардың да әр кейіпкерге тәнті болып, ерлікпен қаза тапқан қайсар жауынгерлердей болуға ұмтылды. Яғни бұл өскелең жас ұрпақты батырлыққа, өжеттілікке, адалдыққа, отансүйгіштік пен патриотизмге баулийтын тәлім-тәрбие құралының біріне айналды. Автор талай рет өз шығармаларының сүйікті жауынгерлеріне арналатын ескерткіш екендігін қашанда баса айтқан. Себебі қан майданда жасалған әрбір ерлікті елеусіз қалдыруды өзіне күнә, арына түсетін қара таңба деп санаған Б.Момышұлы өз шығармаларында тек қана шындықты айтуды мақсат етті. «Өтіріктің балын жалап тірі жүргенше, шындықтың уын ішіп өлген артық» деген аталы сөзді өмірлік ұстанымы етіп өткен батыр бабамыз шындықты жеткізуші ғана емес, оның насихаттаушысы да болды.

Жалпы алғанда, қазақ әдебиетінде Ұлы Отан соғысы тақырыбын жете меңгеріп, қазақ әскери прозасының негізін қалаған бірден-бір жазушы - осы Б.Момышұлы болатын. Оның әдеби мұрасын зерттеуге алғанда, ерлік тұлғасын және Ұлы Отан соғысы жылдарында жазылған отансүйгіштікке тәрбиелейтін шығармаларын зерделеп ескеру қажет.

«Адамға деген қалтқысыз сүйіспеншілік оның бітім-болмысымен біте қайнасқан айрықша қасиет болатын. Ұрыстың қайнаған ортасына, жанған оттың ішіне көзжұмбайлықпен қойып кетіп жүруінің өзінде оның қарауындағы жауынгерлік риясыз жақсы көрген жүрек-сезімі, отаншылдық сезімі жататын. Біз Баукеңнің үлкен әдебиетке келуінен де сол өз солдаттарына деген сүйіспеншілігін көреміз. Шынында да Баукең жазушылық ерлігін Отан үшін опат болған өз солдаттары, майдандас жауынгер достары үшін атқарып шыққан еді» [4, 228-б] - деп белгілі қаламгер Тахауи Ахтанов Бауыржан Момышұлының жазушылық өнерінің қайнар көздерін анықтайды.

\section{References:}

1. М. Қаратаев. Таңдамалы шығармалар, 3 томдық, Т.3., - Алматы: Жазушы, 1974 ж.

2. С.И. Журавлев. Память пылающих лет. Современная советская проза о Великой Отечественной войне. - Москва: Просвещение, 1985 г.

3. . Момышұлы. Қанмен жазылған кітап. - Алматы: Қазақстан, 1991 ж.

4. Бауыржан батыр. - Алматы: Жалын, 1991 ж.

5. Александр Бек. Волоколамское шоссе. [Электронный ресурс] - Режим доступа к тексту: URL: http://militera.lib.ru/prose/russian/bek/01.html (дата доступа 20.06.2014)

6. Момыш-Улы Баурджан. Психология войны: книга-хроника. В двух частях (часть). [Электронный pecypc] - Режим доступа к тексту: URL: http://www.odinvopros.ru/lib/baurdjan_01.php (дата доступа 20.06.2014)

7. Голушко И. М. Солдаты тыла. - М.: Воениздат, 1988. - 270 с.

8. Чистяков И. М. Служим Отчизне. - М.: Воениздат, 1985, стр.70. 